\title{
Paying for hospital care: the experience with implementing activity-based funding in five European countries
}

\author{
JACQUELINE O'REILLY* \\ Research Analyst, Health Research and Information Division, Economic and Social Research Institute, Ireland \\ REINHARD BUSSE \\ Professor and Head of Department of Health Care Management, Berlin University of Technology, Germany \\ UNTO HÄKKINEN \\ Research Professor, Centre for Health and Social Economics, National Institute for Health and Welfare, Finland \\ ZEYNEP OR \\ Research Director, Institute for Research and Information in Health Economics, France
}

ANDREW STREET

Professor of Health Economics, Director, Health Policy team, Director, Economics of Social and Health Care Research Unit, Centre for Health Economics, University of York, England

MIRIAM WILEY

Research Professor and Head of Health Research and Information Division, Economic and Social Research Institute, Ireland

\begin{abstract}
Following the US experience, activity-based funding has become the most common mechanism for reimbursing hospitals in Europe. Focusing on five European countries (England, Finland, France, Germany and Ireland), this paper reviews the motivation for introducing activity-based funding, together with the empirical evidence available to assess the impact of implementation. Despite differences in the prevailing approaches to reimbursement, the five countries shared several common objectives, albeit with different emphasis, in moving to activity-based funding during the 1990s and 2000s. These include increasing efficiency, improving quality of care and enhancing transparency. There is substantial cross-country variation in how activity-based funding has been implemented and developed. In Finland and Ireland, for instance, activity-based funding is principally used to determine hospital budgets, whereas the models adopted in the other three countries are more similar to the US approach. Assessing the impact of activity-based funding is complicated by a shortage of rigorous empirical evaluations. What evidence is currently available, though, suggests that the introduction of activity-based funding has been associated with an increase in activity, a decline in length of stay and/or a reduction in the rate of growth in hospital expenditure in most of the countries under consideration.
\end{abstract}

\footnotetext{
*Correspondence to: Jacqueline O’Reilly, Health Research and Information Division, Economic and Social Research Institute, Whitaker Square, Sir John Rogerson's Quay, Dublin 2, Ireland. E-mail: jacqueline.oreilly@esri.ie
} 


\section{Introduction}

In 1983, the US Medicare programme was the first federal programme to introduce an adjustment for workload complexity within an activity-based funding model for hospital services. The system used to control for workload complexity and relative performance was the Diagnosis-Related Group (DRG) case mix classification system that facilitated the grouping of patients on the basis of their treatment and resource requirements (Wiley, 2005a). Before this switch to a system of funding activity adjusted for complexity, the prevailing approach to reimbursement in the United States was a retrospective cost-based (fee-for-service) system, which was criticised for being inflationary and for providing perverse incentives for inappropriate care (US Congress Office of Technology Assessment, 1985; Kahn et al., 1990). Over the past decade, activity-based funding has become the predominant mechanism for reimbursing hospitals in Europe. The main rationale for moving to activity-based funding is the establishment of a transparent link between funding and activity. For many European healthcare systems, this link tended to be somewhat obscured where global budgets were the main mechanism for reimbursing hospitals.

Economic theory posits that by reimbursing hospitals on the basis of a fixed rate per unit of activity (adjusted for complexity), activity-based funding should provide a financial incentive to increase activity that is absent under global budgets. Compared with retrospective fee-for-service systems, improved efficiency (through minimising costs and input use) would also be encouraged (Aas, 1995; Newhouse, 1996; Ellis, 1998; Kutzin, 2001; Jegers et al., 2002; Langenbrunner and Wiley, 2002; Langenbrunner et al., 2005; Busse et al., 2011). Left unchecked, though, pure activity-based funding could lead to unintended adverse consequences, such as patient selection, inappropriate treatment and quality skimping (Aas, 1995; Ellis, 1998; Jegers et al., 2002).

The main purpose of this paper is to examine the motivation for introducing activity-based funding systems, as well as their implementation, in five European countries - England, Finland, France, Germany and Ireland. The paper also attempts to discuss the impacts of this reimbursement mechanism, although empirical evaluations are still somewhat scarce. The five European countries were selected to illustrate how activity-based funding has been implemented in healthcare systems with differing organisational structures, financing systems and public/private sector involvement in the provision of hospital services. While there are some similarities across these countries in why activity-based funding was adopted, clear and significant differences are evident in how the funding system has been adapted and implemented. In England, France and Germany, the operation of activity-based funding appears to follow a more conventional model compared to either Finland or Ireland, in that prices are fixed $e x$ ante. In Finland, the system is used to determine prices principally for the purposes of hospital billing, although these prices may be subject to change 
ex post to ensure the allocation of adequate funding to hospitals (Vuorenkoski et al., 2008; Häkkinen, 2010). In Ireland, activity-based payment is used to adjust hospital budgets for workload complexity and relative performance (McDaid et al., 2009; Brick et al., 2010).

\section{Timing and motivation}

Table 1 summarises when and how activity-based funding was introduced in the selected European countries. For studies on the adoption and implementation of activity-based funding in other European countries and elsewhere, see, inter alia, Ettelt et al., 2006; Street et al., 2007; Moreno-Serra and Wagstaff, 2010. In Ireland in 1993, following a recommendation of the Commission on Health Funding, an adjustment to hospital budgets based on relative performance and complexity-adjusted activity was introduced (Commission on Health Funding, 1989; Wiley, 2005b; McDaid et al., 2009). Since its introduction, the scope of activity-based funding has expanded in Ireland with almost a threefold increase in the number of participating hospitals (O'Reilly et al., 2011). In Finland, the move away from the incumbent system of per diem prices towards case-based payments followed the 1993 reforms under which state subsidies for health care were paid to municipalities, which were charged with financing hospital care for their residents (Mikkola and Häkkinen, 2002; Mikkola, 2003). In 1997, one of the 21 hospital districts in Finland adopted DRGs as a case-based payment method, with the subsequent adoption throughout the hospital system during the early part of the following decade (Mikkola and Häkkinen, 2002; Häkkinen, 2005; Häkkinen and Linna, 2005). Currently, 13 out of the 21 districts are using DRG-based pricing (Häkkinen, 2010; Kautianen et al., 2011).

In England, France and Germany, activity-based funding was introduced at a national level over a number of years during the 2000s. Even though block contracts had proved to be effective at containing costs in England, they were abandoned in favour of activity-based funding, which was consistent with the prevailing political commitment to reducing waiting lists, facilitating patient choice and encouraging competition between providers (Miraldo et al., 2006; Street, 2006; Street and Maynard, 2007). Since the beginning of the 1990s, DRGs have been promoted in France for measuring hospital activity. Initially, to gain doctors' acceptance, DRGs were presented as an epidemiological tool for monitoring patients (Michelot and Rodrigues, 2008). Over time, the discourse has changed and activity-based payment using DRGs came to be seen as a good alternative to global budgets - the precursor to activity-based funding for public hospitals - which were considered deficient because they did not reflect the costs and volume of services provided (Bellanger and Tardif, 2006; Ettelt et al., 2006). Moreover, private-for-profit hospitals, which provide more than half of all surgery in France, were paid by a mixture of per diem and fee-for-service. The introduction of a payment scheme based on activity was seen as a way of 
Table 1. Timeline and process of introducing activity-based funding

\begin{tabular}{|c|c|c|c|c|c|}
\hline & England & Finland & France & Germany & Ireland \\
\hline $\begin{array}{l}\text { Year of initial } \\
\text { introduction of } \\
\text { activity-based funding }\end{array}$ & 2003-2004 & 1997 & $2004-2005^{\mathrm{b}}$ & 2003-2004 & 1993 \\
\hline $\begin{array}{l}\text { Process of introducing } \\
\text { activity-based funding }\end{array}$ & $\begin{array}{l}\text { Phased in over a } \\
\text { four-year period to } \\
2007-2008^{a}\end{array}$ & $\begin{array}{l}\text { Introduced on voluntary } \\
\text { basis in some hospital } \\
\text { districts }\end{array}$ & $\begin{array}{l}\text { Phased introduction for } \\
\text { public hospitals } \\
(2004-2008)^{c}\end{array}$ & $\begin{array}{l}\text { Introduced in four } \\
\text { stages }\end{array}$ & $\begin{array}{l}\text { Phased introduction for } \\
\text { public hospitals }\end{array}$ \\
\hline $\begin{array}{l}\text { Incumbent } \\
\text { reimbursement } \\
\text { mechanism }\end{array}$ & $\begin{array}{l}\text { Block budgets and } \\
\text { cost and volume } \\
\text { contracts }\end{array}$ & $\begin{array}{l}\text { Per case and per diem } \\
\text { payments }\end{array}$ & $\begin{array}{l}\text { Public and private } \\
\text { not-for-profit hospitals: } \\
\text { Global budgets } \\
\text { private-for-profit } \\
\text { hospitals: Per diem } \\
\text { payments and } \\
\text { fee-for-service }\end{array}$ & $\begin{array}{l}\text { Per case and per diem } \\
\text { payments }\end{array}$ & Global budget \\
\hline \multicolumn{6}{|l|}{$\begin{array}{l}\text { Characteristics of } \\
\text { healthcare system }\end{array}$} \\
\hline $\begin{array}{l}\text { Access to hospital } \\
\text { services }\end{array}$ & $\begin{array}{l}\text { Universal, free at } \\
\text { point of use }\end{array}$ & Universal & Universal & Universal & $\begin{array}{l}\text { Universal, although not } \\
\text { necessarily free at poin } \\
\text { of use }\end{array}$ \\
\hline $\begin{array}{l}\text { Provision of hospital } \\
\text { services }\end{array}$ & $\begin{array}{l}\text { Predominantly public } \\
\text { sector }\end{array}$ & $\begin{array}{l}\text { Public and private } \\
\text { sectors }\end{array}$ & $\begin{array}{l}\text { Public and private } \\
\text { sectors }\end{array}$ & $\begin{array}{l}\text { Public and private } \\
\text { sectors }\end{array}$ & $\begin{array}{l}\text { Predominantly public } \\
\text { sector }\end{array}$ \\
\hline $\begin{array}{l}\text { Main source of } \\
\text { financing }\end{array}$ & General taxation & General taxation & Social insurance & Social health insurance & General taxation \\
\hline
\end{tabular}

${ }^{a}$ But applied with immediate effect to foundation trusts.

${ }^{\mathrm{b}}$ Applies to all hospitals since 2008 .

${ }^{\mathrm{c} A p p l i e s ~ t o ~ p r i v a t e ~ h o s p i t a l s ~ s i n c e ~ 2005 . ~ P r i c e s ~ a r e ~ a d j u s t e d ~ f o r ~ a l l ~ h o s p i t a l s ~ u n t i l ~} 2012$ (Or, 2009).

Sources: Commission on Health Funding (1989), Mikkola and Häkkinen (2002), Häkkinen (2005), Häkkinen and Linna (2005), Wiley (2005b), Bellanger and Tardif (2006), Epstein and Mason (2006), Ettelt et al. (2006), Miraldo et al. (2006) and Ettelt and Nolte (2010). 
stimulating competition between public and private providers, thereby creating a level playing field (Or, 2009). In Germany, activity-based funding replaced a mixed system of per case and per diem payments, limited by hospital budgets, which potentially had contributed to prolonging hospitalisation beyond that medically necessary (Lungen and Lapsley, 2003; Busse and Riesberg, 2004; Lungen et al., 2004; Böcking et al., 2005). Thus, despite different pre-existing reimbursement regimes, all five countries have chosen to implement reimbursement reform and to move to a form of activity-based funding within the space of a decade or so.

The introduction of activity-based funding was generally phased in over several years, allowing hospitals and funders time to adjust to the new reimbursement mechanism, thereby reducing the likelihood of any potential destabilisation. However, the length of time for implementation and the methods of adjustment varied between countries. Initially, the application of activity-based funding was restricted to particular hospitals (e.g. foundation trusts in England) and/or relatively small proportions of hospital activity (as in England and France), with initial losses (relative to previous reimbursement) limited (as in Germany). In addition, reimbursement rates were partially determined by hospitals' own costs in all countries (see Busse et al., 2011 for country details). In Ireland, for example, the budgetary adjustment was initially calculated on the basis of $85 \%$ of a hospital's own costs and $15 \%$ of those of its peer group. By 2011, the share determined by a hospital's own cost profile had fallen to $20 \%$. A similar approach was adopted in Germany where state-wide base rates were phased in over a fiveyear period (ending in 2009) during which there was gradual convergence of hospital-specific reimbursement rates. In France, national DRG prices will be adjusted for each provider's own historical costs up until 2012. Over time, then, countries are moving away from hospital-based reimbursement rates, which is consistent with Shleifer's theory of yardstick competition which posited that potential efficiency gains are maximised when reimbursement rates are entirely independent of a hospital's own costs (Shleifer, 1985).

Despite variation across the five countries in implementing activity-based funding, Table 2 indicates that there were some common policy objectives, which these disparate systems were expected to achieve, although the emphasis on particular aims varied across countries. In England, for instance, improving efficiency had a high priority, while in France, where private hospitals have a major role in delivering surgery and there is no apparent problem with waiting times, relatively more emphasis was placed on improving transparency and fairness of funding between public and private providers, together with delivering better quality care. A number of objectives were mutually re-enforcing: expanding activity would be expected to help to reduce waiting lists ceteris paribus. Others, though, were diverse and potentially conflicting: enhancing efficiency could encourage hospitals to minimise costs to the possible detriment of the quality of care. Thus, activity-based funding alone cannot achieve all of 
Table 2. Policy objectives for introducing activity-based funding

\begin{tabular}{|c|c|c|c|c|c|}
\hline & England & Finland & France & Germany & Ireland \\
\hline Increase efficiency & 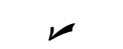 & & & レ & 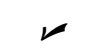 \\
\hline Expand activity & レ & & & & \\
\hline Facilitate patient choice & レ & & & & \\
\hline Reduce waiting lists & $\nu$ & & & & \\
\hline Improve quality & レ & & レ & レ & \\
\hline $\begin{array}{l}\text { Ensure the fair allocation of resources } \\
\text { (or funding) across geographical areas, } \\
\text { and across and within healthcare sectors }\end{array}$ & & レ & $\nu$ & $\nu$ & 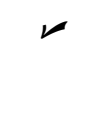 \\
\hline $\begin{array}{l}\text { Improve transparency of hospital funding, } \\
\text { activity and management }\end{array}$ & レ & & $\boldsymbol{V}$ & $\boldsymbol{\nu}$ & $\boldsymbol{V}$ \\
\hline To cover costs of production & & $\boldsymbol{}$ & & & \\
\hline $\begin{array}{l}\text { Create a level playing field for payments } \\
\text { to public and private hospitals }\end{array}$ & $\boldsymbol{\nu}$ & & $\boldsymbol{\nu}$ & & \\
\hline $\begin{array}{l}\text { Improved documentation of internal } \\
\text { processes and increased managerial } \\
\text { capacity which would in turn result in } \\
\text { improved efficiency and quality }\end{array}$ & & & & $\boldsymbol{\nu}$ & \\
\hline $\begin{array}{l}\text { Establish link between activity and } \\
\text { funding }\end{array}$ & レ & 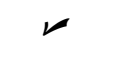 & & & レ \\
\hline
\end{tabular}

Sources: Commission on Health Funding (1989), Wiley (2005b), Bellanger and Tardif (2006), Epstein and Mason (2006), Ettelt et al. (2006), Miraldo et al. (2006) and Ettelt and Nolte (2010).

these objectives and, therefore, other instruments are required. Indeed, attainment of these objectives is likely to be influenced by other policies, which also make it difficult to attribute changes to the implementation of activity-based funding.

\section{Implementation}

Although activity-based funding is common to the countries under consideration, there is substantial cross-country variation in how this mechanism has been implemented and developed. What follows compares the three main components (namely, activity covered and calculation of costs and prices) of activity-based funding in these five countries. This section concludes with an overview of the specific rules within which activity-based funding operates in each of the five countries.

\subsection{Hospital activity}

Table 3 outlines the breadth, depth and scope of hospital activity subject to activity-based funding in each of the five countries under study. On breadth, all relevant hospitals are mandated to participate in activity-based funding in 
Table 3. Breadth, scope and depth of hospital activity subject to activity-based funding

\begin{tabular}{|c|c|c|c|c|c|}
\hline & England & Finland & France & Germany & Ireland \\
\hline $\begin{array}{l}\text { Breadth - hospital } \\
\text { participation }\end{array}$ & & & & & \\
\hline $\begin{array}{l}\text { Mandatory } \\
\text { Scope - type of hospital } \\
\text { activity }\end{array}$ & レ & $\mathrm{X}$ & $\nu$ & $レ$ & For selected hospitals \\
\hline Inpatient and day case & $\boldsymbol{\nu}$ & $\boldsymbol{\nu}$ & $\boldsymbol{\nu}$ & $\boldsymbol{\nu}$ & $\boldsymbol{\nu}$ \\
\hline Outpatient & $\boldsymbol{\nu}$ & $\boldsymbol{\nu}$ & $\mathrm{X}$ & $\mathrm{X}$ & $\boldsymbol{\nu}$ \\
\hline Exclusions & $\begin{array}{l}\text { - Renal dialysis, } \\
\text { selected inpatient } \\
\text { and outpatient } \\
\text { treatments and } \\
\text { high cost drugs and } \\
\text { devices } \\
\text { - } \text { Mental health } \\
\text { services } \\
\text { - Education } \\
\text { - Research and } \\
\text { development }\end{array}$ & $\begin{array}{l}\text { - Varies by hospital } \\
\text { district, but } \\
\text { generally } \\
\text { psychiatric care } \\
\text { and long-term } \\
\text { intensive care } \\
\text { treatment } \\
\text { - Teaching and } \\
\text { research }\end{array}$ & $\begin{array}{l}\text { - Emergency activity, } \\
\text { psychiatric care, } \\
\text { long-term care, } \\
\text { rehabilitation } \\
\text { - Education, } \\
\text { research and } \\
\text { innovation-related } \\
\text { activities } \\
\text { - Activities of } \\
\text { general public } \\
\text { interest } \\
\text { - Financing } \\
\text { infrastructure } \\
\text { investments } \\
\text { contracted with the } \\
\text { Regional Hospital } \\
\text { Authorities }\end{array}$ & $\begin{array}{l}\text { - Psychiatric care, } \\
\text { psychosomatic } \\
\text { care, psycho- } \\
\text { therapeutic care } \\
\text { - Teaching and } \\
\text { research } \\
\text { - Quality assurance } \\
\text { measures } \\
\text { - Accommodation } \\
\text { costs for } \\
\text { accompanying } \\
\text { persons } \\
\text { - Specialist centres } \\
\text { - Innovative } \\
\text { diagnostic and } \\
\text { treatment } \\
\text { procedures }\end{array}$ & $\begin{array}{ll}\text { - } & \text { Non-acute } \\
& \text { psychiatry care } \\
\text { - } & \text { Long-term care } \\
\text { - } & \text { Rehabilitation } \\
\text { - } & \text { Research }\end{array}$ \\
\hline
\end{tabular}


Table 3. (Continued)

hospital activity

Classification system

HRG

Nord DRG

GHM

G-DRG

$1200^{\mathrm{d}}$

AR-DRG $^{\mathrm{e}}$

$698^{\mathrm{f}}$

AR-DRG, Australian Refined Diagnosis-Related Group; DRG, diagnosis-related group; HRG, Healthcare Resource Group; GHM, Groupe Homogène des

Malades; G-DRG, German DRG.

${ }^{a}$ Based on HRG4.

${ }^{\mathrm{b}}$ Based on 2008 version of the FullDRG, which includes DRGs for inpatient care, day surgery and scheduled and emergency visits.

'Based on version 11.

${ }_{\mathrm{d}}^{\mathrm{B}}$ Based on the 2010 grouper.

${ }^{\mathrm{e}}$ Applies to day case and inpatient activity. Treatment Related Groups are used for outpatient activity.

${ }^{\mathrm{t}}$ Based on Version 6.0.

Sources: Ettelt and Nolte (2010), NHS Information Centre (2010), Department of Health (2011), Geissler et al. (2011), Kautianen et al. (2011), Kobel et al. (2011),

Mason et al. (2011), Or and Bellanger (2011) and O'Reilly et al. (2011). 
England, France and Germany. In the latter, though, a small number of specialised hospitals providing highly complex care have been excluded from the scheme (Ettelt and Nolte, 2010). Full hospital participation minimises the potential for cost shifting to other institutions within the acute hospital sector, but hospitals may still try to minimise their own costs by transferring patients to other parts of the healthcare system that are not subject to this form of reimbursement. ${ }^{1}$

Conversely, not all Irish public hospitals participate in the prevailing activitybased funding scheme, although there are plans to continue to extend the scheme to incorporate additional public hospitals (Brick et al., 2010). The 2010 budgets of 39 acute public hospitals (accounting for 92\% of activity) were adjusted for case mix (Health Service Executive, 2010a). These participating hospitals are typically larger than non-participants. In Finland, the adoption of DRG-based pricing is determined by hospital districts (Häkkinen, 2010). The decentralised nature of the Finnish healthcare system, together with the absence of national guidance on the operation of activity-based funding, means that there is considerable variation across hospital districts in the design and implementation of the scheme at the cost of reduced transparency and comparability (Häkkinen, 2005).

All five countries currently use activity-based funding to reimburse almost all day-case and acute inpatient activities. There are, however, some notable exceptions. For example, it has been recognised that it is particularly difficult to apply activity-based funding in mental health care due to issues concerning the classification of related diagnoses and the considerable variation in patient costs (Ettelt et al., 2006). However, there are plans in England, France and Germany to extend activity-based funding to this area (Mason and Goddard, 2009; Geissler et al., 2011; Mason et al., 2011; Or and Bellanger, 2011). A combination of annual grants and fee-for-service is used to reimburse hospitals for emergency activity in France (Or, 2009). Most typically, hospitals receive separate funding for teaching and research activities, the costs of which may not be adequately reflected in prices under activity-based funding.

Three of the five countries apply activity-based funding to outpatient activity. In Germany, there is strict organisational division between the provision of inpatient and outpatient services: regional physicians' associations have an effective monopoly over the provision of ambulatory care, while hospitals are permitted to only undertake inpatient care (Busse and Riesberg, 2004; Schreyögg et al., 2005; Greß et al., 2006). This separation has prohibited the extension of activity-based funding to outpatient activity. In France, outpatient services provided in hospital are paid by a fee-for-service schedule, as in the ambulatory sector.

1 For instance, outpatient activity was not initially included in the US Medicare activity-based payment system, but instead was funded on a fee-for-service basis (Rosenberg and Browne, 2001; Friesner and Rosenman, 2004; Böcking et al., 2005; Ellis and Vidal-Fernández, 2007). Consequently, there was a shift from inpatient to outpatient treatment and the prospective payment system was subsequently extended to include outpatient activity in 2000 (Rosenberg and Browne, 2001). 
The scheme used for classifying activity into groups with similar resource use and clinical characteristics is a crucial component of activity-based funding. In this, too, significant cross-country differences are apparent (Table 3). Interestingly, each country has adopted a different classification scheme for inpatient activity, although these are all closely related to the first classification system adopted by the US Health Care Financing Administration (Schreyögg et al., 2006a). The successful export of DRGs from the United States to Europe has been influenced by several factors, including their use in the former for prospective payment, their flexibility and the availability of technology and support at relatively low cost (Kimberly et al., 1993, 2008). The Australian scheme, Australian Refined DRGs, was adopted in Germany (with modifications) and in Ireland. The utility of employing such diverse classification systems, even for describing relatively homogenous hospital services, could be questioned, but local adaptations reflect a desire to secure clinical ownership and acceptance of the classification system.

There is considerable variation in the number of groups each country's scheme uses: the number of DRGs in France, for example, is more than three times that in Ireland (see Table 3). This arises from the introduction of a new version of DRGs in France where the number of groups has been expanded to allow for case severity and short-stay DRGs (Or and Bellanger, 2011). There is no consensus in the literature on the optimum number of groups and there are advantages and disadvantages associated with schemes that have more or fewer groups. From a theoretical perspective, the benefits of fewer groups (and, consequently, more broadly defined categories) in terms of promoting efficiency and reducing the scope for data manipulation must be offset against the potential disadvantages of cherry picking lower-cost patients and skimping on quality (Busse et al., 2006). Such concerns over quality and access may be negated by expanding the number of groups, although in addition to potentially increasing the complexity of data coding, the prospective power of the system may be greatly diminished if the number of patients per group is too small. At the extreme, a very fine DRG classification could be similar to fee-for-service reimbursement (Busse et al., 2006). In France, there currently is an absence of evidence on whether doubling the number of groups in 2009 helped to reduce unintended consequences such as data manipulation and gaming.

\subsection{Hospital cost}

As with the activity data, the five countries have adopted different approaches to collating cost data (Table 4). The bottom-up approach, as used in Germany and Finland, is essentially based on patient-level data on resource utilisation to which unit cost data are applied (Street et al., 2007). Patient-level costing is considered more accurate because it is based on actual, rather than average, resource utilisation (Leister and Stausberg, 2005; Street et al., 2007). In the absence of patient-level 
Table 4. Approaches to collation of cost data

\begin{tabular}{|c|c|c|c|c|c|}
\hline & England & Finland & France & Germany & Ireland $^{\mathrm{e}}$ \\
\hline $\begin{array}{l}\text { Cost accounting } \\
\text { methodology }\end{array}$ & Top-down & Bottom-up & Top-down ${ }^{c}$ & Bottom-up & Top-down \\
\hline Sample & $\begin{array}{l}\text { All National Health } \\
\text { Service (NHS) } \\
\text { hospitals }^{\mathrm{a}}\end{array}$ & $\begin{array}{l}\text { All hospitals in } \\
\text { the largest } \\
\text { hospital district }\end{array}$ & Sample & Sample & All selected hospitals \\
\hline $\begin{array}{l}\text { Number (\%) of } \\
\text { hospitals in sample }\end{array}$ & All NHS hospitals & $5(15)$ & $99(5)$ & $125(6)$ & $39(100)$ \\
\hline $\begin{array}{l}\text { Inclusion of capital } \\
\text { costs }\end{array}$ & $\boldsymbol{\nu}^{\mathrm{b}}$ & $\nu$ & $\boldsymbol{\nu}$ & $X^{d}$ & $\mathrm{X}$ \\
\hline
\end{tabular}

${ }^{a}$ Cost data are from NHS hospitals only. Private providers, to which activity-based funding is now being extended when they care for NHS patients, do not provide cost data (Mason et al., 2009).

${ }^{\mathrm{b}}$ Covered through activity-based funding and separate grants.

${ }^{\mathrm{c}} \mathrm{A}$ small proportion of costs are determined at patient level (Bellanger and Tardif, 2006).

${ }^{\mathrm{d}}$ Financed by the state governments.

${ }^{\mathrm{e}} \mathrm{A}$ pilot project was initiated in 2009 to assess potential approaches to patient-level costing (Health Service Executive, 2010c).

Sources: Häkkinen and Linna (2005), Leister and Stausberg (2005), Schreyögg et al. (2006a, 2006b), Ettelt and Nolte (2010), Geissler et al. (2011), Kautianen et al. (2011), Mason et al. (2011), Or and Bellanger (2011), O’Reilly et al. (2011) and Tan et al. (2011). 
data, a top-down approach, as currently implemented in England, France and Ireland, involves the allocation of relevant hospital expenditure to particular services or specialties (Street et al., 2007). Patient-level information and costing systems are being implemented in England; however, as of yet, these are not mandatory (Department of Health, 2009). In Ireland, a pilot project to collate patient-level costs is underway (Health Service Executive, 2010c).

Cost data can be supplied by a sample of hospitals (as in Finland, France and Germany), or, alternatively, by the full hospital population participating in activitybased funding (as in Ireland). There are advantages and disadvantages associated with both approaches (Schreyögg et al., 2006a). A sample-based approach should ensure good data quality at a relatively low administrative cost by ensuring that participating hospitals provide data in a consistent format. However, financial payments for hospitals had to be introduced in France and Germany to incentivise the provision of high-quality data in the required format (Schreyögg et al., 2006a). The payment to German hospitals participating in the voluntary data-sharing programme comprised a fixed component and a variable fee dependent on the quality of the data submitted (Schreyögg et al., 2005). One important potential disadvantage of using a sample is that it may not be representative, a charge that has been levied against the French and German samples (Bellanger and Tardif, 2006; Schreyögg et al., 2006b). The latter has been criticised for being biased towards medium and large hospitals and for a low participation rate among public and private hospitals (Schreyögg et al., 2006b). Convincing French private hospitals to provide their cost data has proved to be particularly difficult. Schreyögg et al. (2006a) argue that achieving full participation is dependent on hospital ownership and the ability of the price-setting agency to gain access to the requisite data. Thus, obtaining data on all participating hospitals is relatively easier in Ireland, where public hospitals are owned and/or funded by the agency responsible for determining the reimbursement rate (Schreyögg et al., 2006a). In England, cost data are from National Health Service (NHS) hospitals only; private providers do not provide cost data, even though activity-based funding applies to them when they provide care for NHS patients (Mason and Goddard, 2009).

The reliability of costing methods, as well as the accuracy and transparency of cost data, are essential for the functioning of activity-based funding. In France, for example, the lack of transparent cost data to identify efficient providers and to facilitate an understanding of differences in clinical practice are issues to be addressed in the ongoing development of the activity-based funding system (Or and Bellanger, 2011).

The mechanisms for financing capital costs vary across the five countries (Table 4). By excluding capital costs from activity-based funding (as in Germany and Ireland), local, regional or national governments have retained control over decisions regarding, in particular, the planning of new hospital buildings and equipment. That hospitals should be able to control their costs subject to activity-based funding, at least in the short term, is a further argument for 
omitting capital costs from this funding system (Schreyögg et al., 2006a). In France and England, capital costs are (at least in principle) included in DRG prices. However, an unmeasured part of capital costs is funded through specific payments to French public hospitals to help them finance costly investment plans imposed by the recent healthcare reforms (Or and Bellanger, 2011).

\subsection{Determining the price/tariff}

Prices are set at a national level in three of the five countries considered (England, France and Ireland). In Germany, it has been agreed that the 16 base rates at state level will gradually converge to a narrow range at federal level between 2010 and 2014. At the end of this period, the acceptable regional variation will be between $+2.5 \%$ and $-1.25 \%$. After 2015, a decision, informed by research on the reasons for variation in the state base rates, will be made about the possibility of having a single federal rate (Ettelt and Nolte, 2010). Under the decentralised healthcare system in Finland, prices vary across hospital districts, reflecting payment systems decided at local levels. However, nationally determined prices may also incorporate local factors. For instance, in England, the Market Forces Factor allows prices to be adjusted for local variation in input prices (Street and Maynard, 2007; Mason et al., 2009).

Although all providers - public and private - treating publicly funded patients are subject to activity-based funding in England, France and Germany, they may not necessarily face the same price. In France, the tariff applied to public and private not-for-profit hospitals includes all costs associated with a hospital stay, while the equivalent for private-for-profit hospitals excludes doctors' fees. It was intended that the prices in the two sectors would converge by 2012, but this deadline was recently extended to 2018 (Or, 2009). Whether the public and private sectors should face the same tariffs is an issue of some debate. A uniform tariff may be expected to increase competition between the public and private sectors ceteris paribus. However, if hospitals' costs are not entirely within their control, such competition may be deleterious to quality of care. Moreover, ignoring structural differences between hospitals in setting prices may endanger the system's capacity to provide necessary (complex) care as well as equity of access. Therefore, differentiated tariffs can be used to adjust for exogenous cost differences and, thereby, create a 'fair playing field' between the public and private sectors (Mason et al., 2009: 385).

In all five countries, average costs are used as the basis for determining the tariff. This has been criticised on a number of grounds. First, rewarding hospitals at full average cost for activity provides an incentive to increase activity as long as marginal cost is less than or equal to price/average cost; this could result in the provision of care that is financially unsustainable and/or medically inappropriate (Mannion et al., 2008). Second, the association between prices and average cost encourages convergence to the mean, rather than incentivising improvement in 
performance (Street and Maynard, 2007). To secure performance improvements in 2010-2011, the English Department of Health imposed a 3.5\% reduction in tariffs (somewhat akin to price-cap regulation), applied across all hospitals irrespective of their current level of performance (Department of Health, 2010). Similarly, the 2011-2012 tariffs have been set at ' $1 \%$ below the mean average of reported costs' (Department of Health, 2011: 12). Third, cost-based prices may not reflect the value of outputs and, therefore, may result in the production of a sub-optimal mix of outputs from a societal perspective (Smith and Street, 2005; Street et al., 2010). Recent initiatives have moved away from average cost pricing in an attempt to encourage quality improvements and to reduce unexplained variation in clinical practice. The introduction of best practice tariffs in England establishes a link between payment and the efficient provision of high-quality care (such as day-case treatment where appropriate, or following evidence-based clinical guidelines or protocols for complex treatments, etc.) (Department of Health, 2010). In Germany, adjustments are made to hospital payments under some 'integrated care' contracts to take account of certain quality indicators (Or and Häkkinen, 2011).

Almost all countries have introduced price adjustments and/or supplementary payment mechanisms in recognition of the inherent limitations of activity-based funding for certain types of activity or cases. Thus, while prices may be determined in advance, adjustments for extreme outlier cases (typically using per diem payments based on length of stay) mean that the system is not truly prospective and that some of the financial risk is shared between funders and providers. In England, a top-up is added to the prices paid to hospitals that undertake specialised services to offset the potentially higher costs they might incur from treating more complex patients (Department of Health, 2010, 2011; Daidone and Street, 2011).

Certain expensive drugs and devices are not subject to activity-based funding in four of the five countries (the exception being Finland), but paid on top of the DRG price (see, e.g. Henschke et al., 2010). In France, expenditure growth in this area greatly outstripped that for activity subject to activity-based funding between 2005 and 2007 (37\% vs 4\%, respectively; Or, 2009). Interestingly, in Germany, the number of supplementary fees available increased from 26 in 2004 when they were introduced to 143 in 2010 (Schreyögg et al., 2005; Geissler et al., 2011). This increase may reflect the inadequacies of activity-based funding to reimburse hospitals for certain complex or cost-intensive services, but may also reveal hospitals' attempts to shift costs to areas not covered by activitybased funding. In England, there is an annually updated list of high cost drugs and devices for which prices are negotiated locally rather than set nationally (Department of Health, 2011).

\subsection{Control mechanisms}

Under a pure form of activity-based funding, hospitals' financial incentive to increase activity could result in unsustainable expenditure and might potentially 
be associated with adverse health outcomes. All five countries under consideration have adopted different approaches to attempt to tackle this issue. In England, Germany and Ireland, the volume of services is agreed at a local level and specified in contracts between hospitals and funders. In England, the extent to which these contracts translate into binding budget constraints is dependent on the size of the budget allocated to the commissioning agency (primary care trust) and its ability to manage demand for hospital services (Mannion and Street, 2005; Oliver, 2005). While evidence suggests that commissioning agencies have been successful in transferring certain services from hospitals to the community, there are concerns that their ability to exercise control over hospital activity and expenditure may be somewhat weakened in the absence of an explicit threshold limit on hospital activity and due to other policies such as patient choice (Street and Maynard, 2007; Mannion et al., 2008).

In Germany, DRG prices are adjusted if services are provided in excess of (below) the volume agreed under the annual contract negotiated between sickness funds and hospitals (Busse and Riesberg, 2004; Geissler et al., 2011). Therefore, the hospital's incentive to increase activity over the agreed level is diminished. In France, too, this strategy is also used, although its practical application differs: if hospital expenditure exceeds a national target level, then all hospitals (regardless of their individual performance) face reduced prices. This has been criticised for creating uncertainty over the prices faced by hospitals (Or, 2009). A more targeted policy of marginal pricing applies to emergency activity in England whereby emergency activity above a threshold based on historic activity levels is reimbursed at a rate of just $30 \%$ of the tariff (Department of Health, 2010).

In Finland, municipalities and hospital districts negotiate the volume and cost of services. The budget of each hospital district is based on these negotiations and is formally decided by a Council (with members appointed by each municipality), which is also responsible for determining the pricing method and the level of prices. If the hospital district budget is exceeded, the municipalities must cover the deficit from their own revenues, usually by paying hospitals higher prices for services. In the case of budgetary surplus, the prices paid by municipalities can be lowered (Häkkinen and Linna, 2005; Häkkinen, 2010). Thus, hospitals have no incentive to keep within budget since any deficit is covered ex post. In contrast, Finnish municipalities must balance annually their resource allocation to hospital care with that to other public services sectors. Increases in hospital costs must be financed either by increasing the local tax rate or by reducing resources allocated to social services (including day care for children), cultural services or sports halls, etc. Hence, municipalities have incentives for efficient cost sharing. There is now increasing evidence that Finnish hospitals are more efficient than hospitals in other Nordic countries (Linna et al., 2006, 2010; Kittelsen et al., 2009). Although there has been no formal research to explain this finding, one possible explanation that has been 
proposed is that Finnish municipalities are more effective at controlling costs than the counties/regions in Sweden and Denmark, or the central government in Norway (Häkkinen, 2010).

\section{Impact}

Formal evaluation of the impact of activity-based funding in the selected countries is largely lacking (Scheller-Kreinsen et al., 2009). Several possible explanations can be advanced for this. First, the relatively recent introduction of activity-based funding in some of these countries means that it may be too soon to assess its impact (especially if there is a lag in the availability of the requisite data). Second, activity-based funding is not implemented in controlled environments and, therefore, it can be difficult to isolate its effect from that of other policies introduced concomitantly. Thus, changes in the parameters of interest may not easily be attributed to the introduction of activity-based funding. Furthermore, the potential for activity-based funding to achieve the objectives of increased activity and improved efficiency may depend on each country's starting point in terms of the previous reimbursement mechanism, as well as the specific design and governance of the new system (Street et al., 2011). In France, for instance, a lack of transparency in price setting and additional payments appear to have contributed to uncertainty within the hospital sector that may ultimately undermine the expected outcomes of activity-based funding.

From a methodological perspective, short study periods may be unlikely to detect changes arising from the introduction of activity-based funding if the reforms have been phased in over a number of years (as has been the case for some of the countries considered in this paper). Conversely, results identified in studies with longer timeframes may be subject to potential confounding factors due to the introduction of other policies during the interim period. Few studies have attempted to control explicitly for the effects of such confounders.

Cognisant of these problems, this section reviews what evidence does exist on the impact of activity-based funding on hospital efficiency, as well as on the quality of care and of clinical data.

A common objective for moving to activity-based funding was to improve hospital efficiency by some combination of increasing activity, reducing costs and introducing an element of competition between hospitals (Table 2). However, no studies of the explicit impact on efficiency per se have been undertaken for the countries under consideration. Nevertheless, some studies have reported changes in indicators of efficiency - in particular, activity, length of stay, costs and quality.

The link between funding and activity under activity-based funding provides hospitals with incentives to increase patient throughput. Indeed, this hypothesis is supported by the empirical evidence in Table 5, which shows that the volume of activity did increase following the introduction of activity-based funding in 
Table 5. Summary of studies of changes in activity, length of stay, cost and quality following introduction of activity-based funding

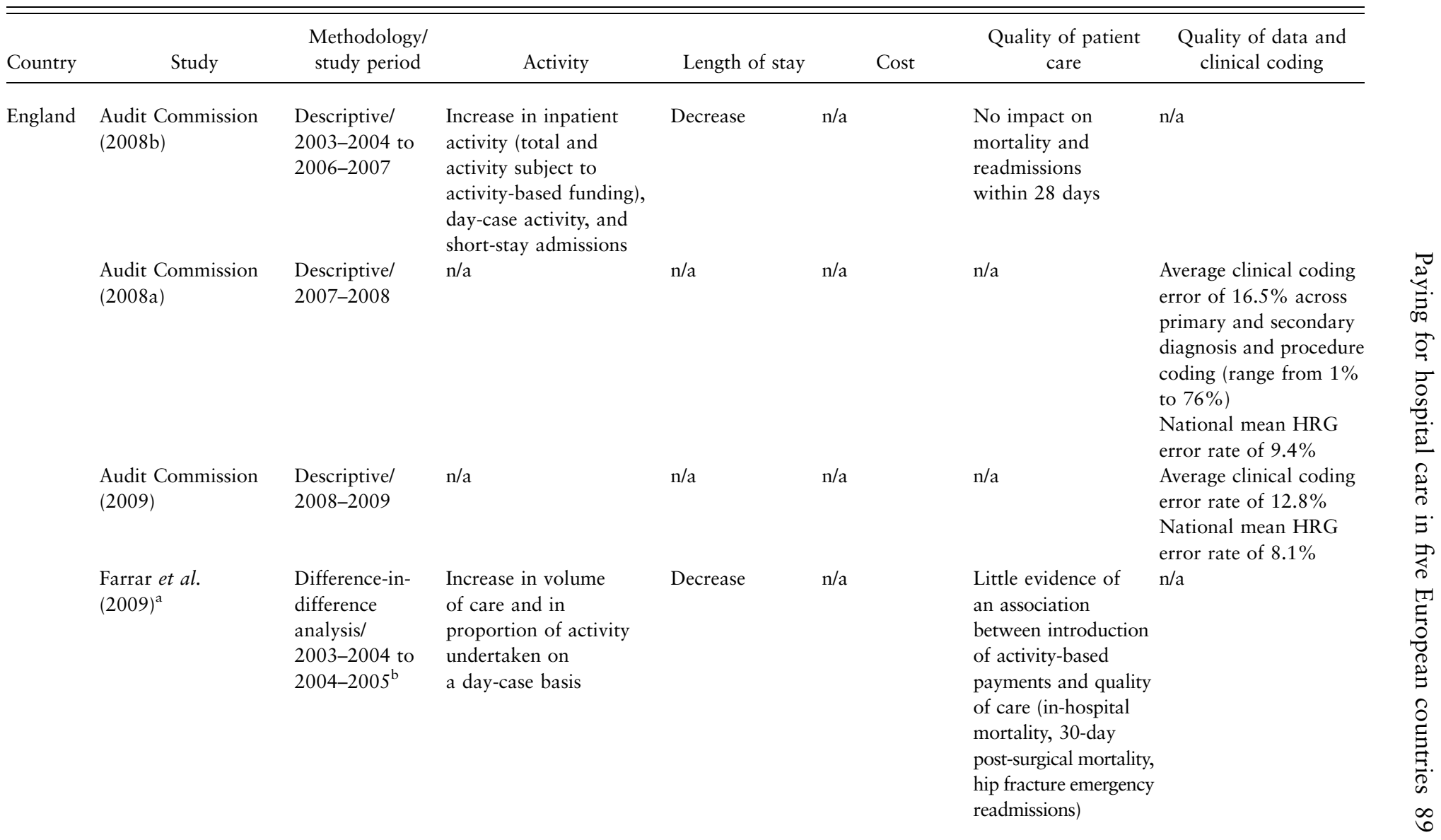


Table 5. (Continued)

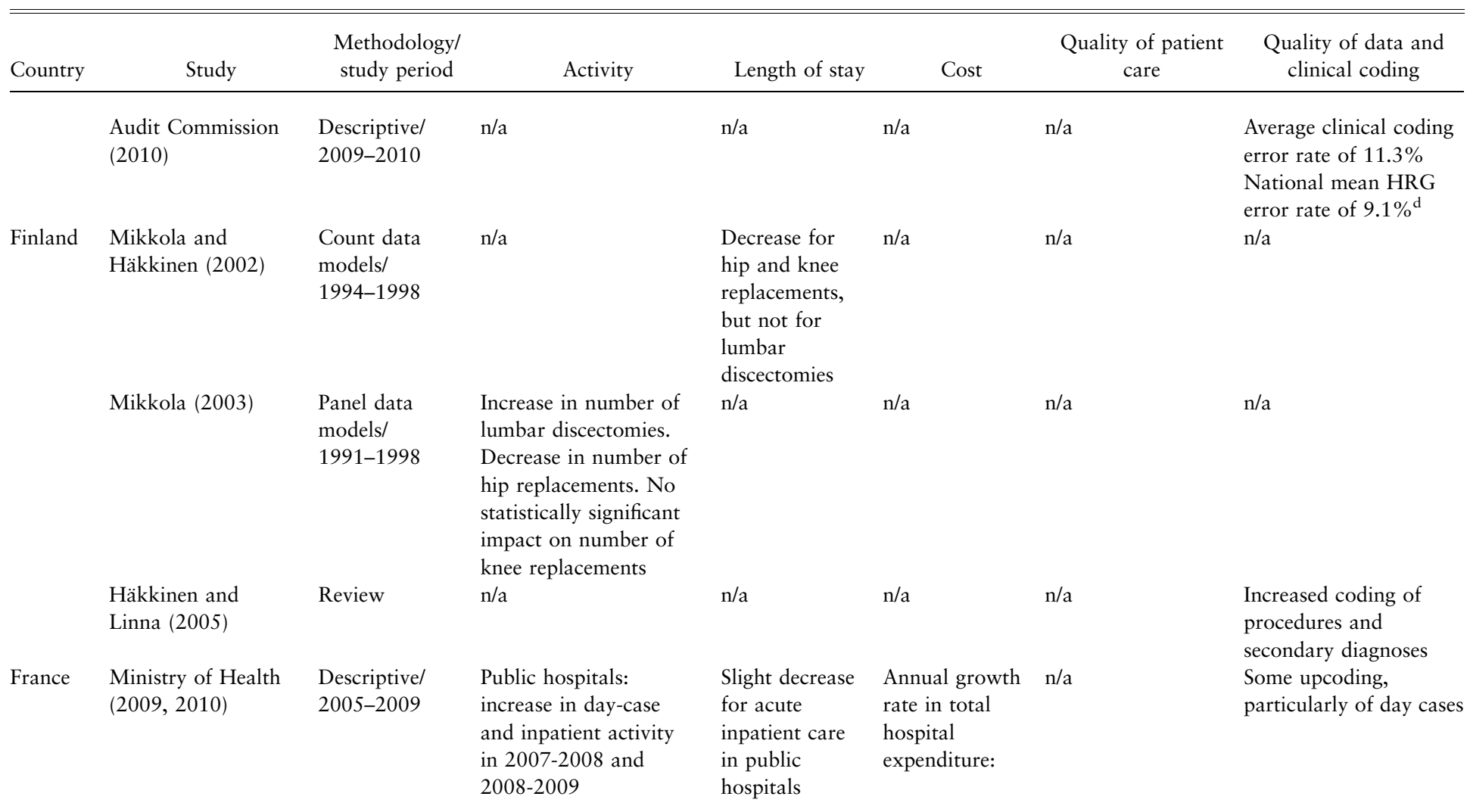


Table 5. (Continued)

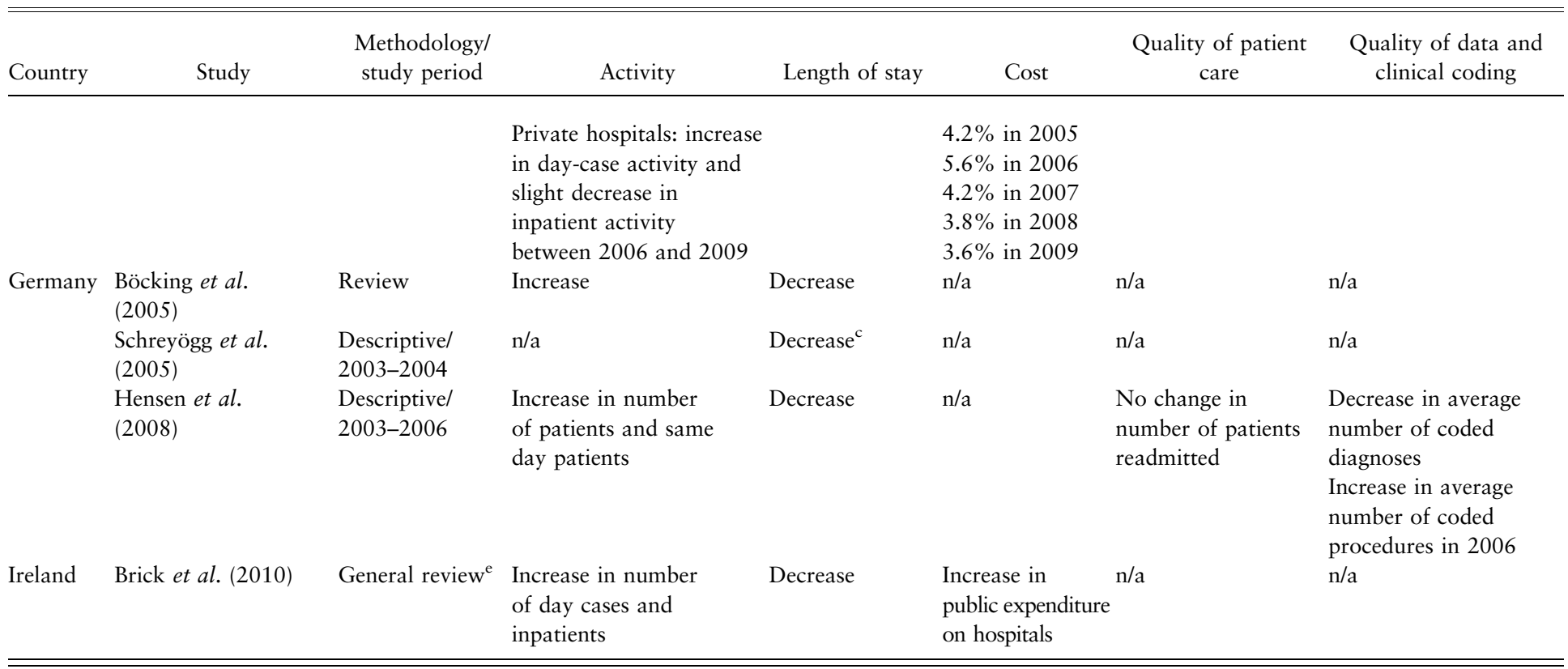

n/a, not available.

${ }^{a}$ Results also reported in Farrar et al. (2007).

${ }^{\text {b}}$ Some results are reported for the period 2003-2004 to 2005-2006.

'The scale of this reduction was consistent with the longer run trend in length of stay (Schreyögg et al., 2005).

${ }^{\mathrm{d}}$ This error rate was calculated on the basis of HRG4, which was introduced in 2009-2010. According to the Audit Commission, this version of HRG4 is more sensitive to coding errors due (principally) to its larger number of HRGs. If HRG4 was used to classify patients in 2008-2009, then there would have been a $1.8 \%$ improvement in the HRG error rate (Audit Commission, 2010).

${ }^{\mathrm{e}}$ General review of trends in public hospital activity, length of stay and expenditure; not specifically focused on assessing changes following the introduction of activity-based funding.

See also O'Reilly et al. (2011). 
England (Farrar et al., 2007, 2009; Audit Commission, 2008b), France (Ministry of Health, 2009, 2010) and Germany (Böcking et al., 2005; Hensen et al., 2008). As noted above, though, factors other than the introduction of activity-based funding may have affected this outcome. For example, in England, the introduction of activity-based funding was contemporaneous with large funding increases to the NHS and the use of other policy instruments, such as waiting time targets, so isolating its specific impact is virtually impossible (Propper et al., 2007; Audit Commission, 2008b; Farrar et al., 2009; see also Sussex and Farrar, 2009).

Not only has hospital activity increased in absolute terms but there has also been a change in its composition. In an attempt to increase patient throughput while minimising costs, hospitals have increased the proportion of activity undertaken on a day-case basis (Farrar et al., 2007; Or, 2009). In England, while attempts to encourage hospitals to shift towards day-case activity date from the 1970s, activity-based funding coupled encouragement with financial incentives: the national elective tariff was set equal to the weighted average costs for inpatients and day cases (Boyle, 2005; Ettelt et al., 2006; Street, 2006; Department of Health, 2007; Ellis and Vidal-Fernández, 2007; Street and Maynard, 2007). With such a tariff, the incentive for hospitals to minimise costs encouraged a more rapid change from (relatively more expensive) inpatient to (relatively less expensive) day-case treatment than had been observed previously (Street and Miraldo, 2007; Farrar et al., 2009). The resulting increase in day-case treatment meant that the national tariff would over time converge towards the average day-case cost, thereby reducing the proportion of inpatient costs covered (Street and Maynard, 2007) and incentivising a further shift to day-case activity.

In France, private for-profit and not-for-profit hospitals have been quick to respond to the new system by increasing their activity, as well as their market share in day cases (Ministry of Health, 2009). There were concerns, however, that some of the increase in day-case activity may be a consequence of deliberate 'up-coding' of activity and/or inappropriate treatment, rather than more efficient service delivery. To avoid potential abuse of the system, the health insurance fund introduced a definition of day-case activity with the result that there was a decline in such activity between 2006 and 2007 (Or and Bellanger, 2011).

Of course, changes in the recording of clinical data following the introduction of activity-based funding may not always serve to misrepresent patient data for the purposes of receiving higher reimbursement. Steinbusch et al. (2007) argue that the risk of upcoding is dependent on the specific design and operation of the DRG systems, as well as broader issues, such as the market characteristics (including the presence of for-profit hospitals) and the instruments employed to prevent upcoding. Thus, the risk of upcoding would be expected to be lower in systems where there are no for-profit providers; coders' remuneration is independent of the outcome of the coding process; the DRG assignment does not take place after discharge; and classification criteria are aligned with clinical practice. In Finland, coding of procedures and secondary diagnoses improved 
following the reimbursement reform, although it could be argued that the Finnish operation of activity-based funding does not provide strong incentives for upcoding (Häkkinen and Linna, 2005). Even in England, though, where there is a more explicit link between coding and payment, the Audit Commission, in its first national audit of clinical data in 2007-2008, concluded that there was little evidence of deliberate upcoding since errors were random, resulting in both positive and negative financial outcomes (Audit Commission, 2008a). The error rate fell in subsequent financial years (Audit Commission, 2009, 2010).

Consistent with increased day-case activity, length of stay has declined in England, Germany and Ireland, although some argue that this was merely consistent with a general trend towards shorter hospital stays (Böcking et al., 2005; Schreyögg et al., 2005; Audit Commission, 2008b; Brick et al., 2010).

The consequences of these changes on costs and quality of care are not straightforward. Increased patient throughput may be expected to result in increased aggregate expenditure on hospital services (as in France; Or, 2009), yet the costs per case may be lower (as in England, proxied by changes in length of stay and share of day-case activity; Farrar et al., 2009). Quality of care might be adversely affected if patients are discharged from hospital 'quicker and sicker'; but shorter hospital stays are associated with a lower probability of acquiring hospital infections ceteris paribus (Kosecoff et al., 1990; Clarke, 1996). Evidence on the effects on the quality of care from the countries under consideration is very limited, but two evaluations found that the quality of English hospital care was not, in fact, adversely affected by the introduction of activity-based funding (Farrar et al., 2007, 2009; Audit Commission, 2008b). However, despite advances in the measurement of patient outcomes and quality of care, on the whole deficiencies remain in most of the countries under study (Or and Häkkinen, 2011). For example, in France, Germany and Ireland, indicators such as readmission rates and complication rates are not routinely available.

\section{Discussion}

In the past decade, activity-based funding has become the most common mechanism for reimbursing hospitals in Europe. In the five countries under consideration here, this reform was aimed at achieving a long and varied list of policy objectives, some of which were common across these countries (e.g. increase efficiency, improve quality, enhance transparency), albeit with differing emphasis. At a cursory glance, there are some broad similarities across countries for example, almost all systems incorporate a form of risk sharing between providers and funders for high cost, complex cases. However, at a more detailed level, it is clear that the schemes have been tailored for the country-specific contexts in which they operate. Thus, the practical implementation of activitybased funding depends on, inter alia, the relationships between providers and funders, the degree of (de)centralisation in the healthcare system, the separation 
between purchasing and provision and the structure of the hospital market (share of private hospitals, level of competition between public and private hospitals, etc.). Alongside these contextual factors, practical considerations are also important: success appears to be contingent on the availability of a robust information system together with flexible and transparent management and governance structures, which can support continuous fine-tuning of the system. The heterogeneity across countries is most evident from the fact that the five countries differ with regard to the DRG scheme adopted or locally developed, together with the approaches pursued for system implementation, costing and pricing. These differences make cross-country comparisons difficult and may limit the extent to which country-specific models of activity-based funding may be transplanted to other countries. Notwithstanding these constraints, what is encouraging is that the sharing of experience, techniques and tools in the international context can greatly assist those working on the development of local models and addressing local implementation issues.

Assessing the success of activity-based funding in achieving the stated policy objectives is complicated by the shortage of formal evaluations, together with their relatively recent adoption. Preliminary indications, though, suggest that following the introduction of activity-based funding, activity increased, length of stay declined and total hospital expenditure grew (albeit at a slower rate). Even so, it is difficult to attribute these changes exclusively to the funding reform due to the presence of confounding factors. Further empirical evaluation is required so that the strengths of this reimbursement model may be exploited and any weaknesses addressed.

Since its adoption by the five countries under consideration, the use of activity-based funding in reimbursing hospitals has evolved and will continue to do so. In England, the tariff has been used as an instrument to encourage a shift from inpatient to day-case treatment, to improve efficiency and, with recent moves away from cost-based to best-practice-based pricing, to ensure evidencebased clinical practice in line with national guidance (Department of Health, 2011). The Irish Health Service Executive has committed to moving to a prospective model of activity-based funding (Health Service Executive, 2010d). In addition, activity-based funding (and the associated information systems) can be used to incentivise improved quality of care (Or and Häkkinen, 2011), as is currently underway in the United States (see, e.g. Pronovost et al., 2008; McNair et al., 2009; Goldfield, 2010). In Germany, for instance, hospitals have an incentive to avoid readmissions because they will not receive additional reimbursement for cases readmitted for the same cause within 30 days of the initial admission (Geissler et al., 2011). A similar rule has been introduced in England (Department of Health, 2011).

The application of activity-based funding is also extending beyond hospital reimbursement. In Ireland, for example, consultants' complexity-adjusted workload is estimated using data derived from the funding model and is the 
basis for monitoring compliance with the ratio of public to private practice specified in their employment contract (Health Service Executive, 2008). Alongside activity-based funding systems, patient classification systems provide a means of quantifying comparative hospital performance. In Finland, the Hospital Benchmarking project provides hospitals with information on efficiency and productivity (Linna and Häkkinen, 2008; Häkkinen, 2010). Similarly, HealthStat in Ireland produces comparative information on hospital performance (Health Service Executive, 2010b).

In the relatively short time period since activity-based funding was adopted in the five European healthcare systems under study, it has already evolved quite rapidly, contributing to efficiency improvements in their acute hospital sectors. The future direction for activity-based funding is clear: further adaptations will be necessary to address fully the increasing emphasis on quality of care and value-based purchasing, as well as to deliver integrated care through episode-based payment (as currently advocated in the United States, see Goldfield, 2010). Extending the reimbursement mechanism beyond the hospital sector will be required if these objectives are to be addressed. The recent developments discussed above indicate that progress is underway on adapting activity-based funding to meet these future challenges.

\section{Acknowledgements}

This paper draws on research undertaken as part of the EuroDRG project 'Diagnosis related groups in Europe: Towards Efficiency and Quality', funded under the 7th EU Framework Programme (Contract number: 223300). The authors are grateful for helpful comments received from Jonathan Sussex, Anna Dixon, Emmi Poteliakhoff, an anonymous reviewer and participants at the Autumn 2010 meeting of the European Health Policy Group.

\section{References}

Aas, I. H. M. (1995), 'Incentives and financing methods', Health Policy, 34(3): 205-220.

Audit Commission (2008a), PbR Data Assurance Framework 2007/08. Findings from the First Year of the National Clinical Coding Audit Programme, London: Audit Commission.

Audit Commission (2008b), The Right Result? Payment by Results 2003-07, London: Audit Commission.

Audit Commission (2009), PbR Data Assurance Framework 2008/09. Key Messages from Year 2 of the National Clinical Coding Audit Programme, London: Audit Commission.

Audit Commission (2010), Improving Data Quality in the NHS: Annual Report of the PbR Assurance Programme, London: Audit Commission.

Bellanger, M. M. and L. Tardif (2006), 'Accounting and reimbursement schemes for inpatient care in France', Health Care Management Science, 9(3): 295-305.

Böcking, W., U. Ahrens, W. Kirch and M. Milakovic (2005), 'First results of the introduction of DRGs in Germany and overview of experience from other DRG countries', Journal of Public Health, 13(3): 128-137. 
Boyle, S. (2005), 'Payment by results in England', Euro Observer, 7(4): 1-4.

Brick, A., A. Nolan, J. O'Reilly and S. Smith (2010), Resource Allocation, Financing and Sustainability in Health Care: Evidence for the Expert Group on Resource Allocation and Financing in the Health Sector, Dublin: Department of Health and Children and Economic and Social Research Institute.

Busse, R., A. Geissler, W. Quentin and M. Wiley (eds) (2011), Diagnosis Related Groups in Europe. Moving Towards Transparency, Efficiency and Quality in Hospitals, Maidenhead: Open University Press.

Busse, R. and A. Riesberg (2004), Health Care Systems in Transition: Germany, Copenhagen: WHO Regional Office for Europe on behalf of the European Observatory on Health Systems and Policies.

Busse, R., J. Schreyögg and P. C. Smith (2006), 'Editorial: Hospital case payment systems in Europe', Health Care Management Science, 9(3): 211-213.

Clarke, A. (1996), 'Why are we trying to reduce length of stay? Evaluation of the costs and benefits of reducing time in hospital must start from the objectives that govern change', Quality in Health Care, 5(3): 172-179.

Commission on Health Funding (1989), Report of the Commission on Health Funding, Dublin: The Stationery Office.

Daidone, S. and A. Street (2011), Estimating the Costs of Specialised Care. CHE Research Paper 61, York: University of York.

Department of Health (2007), 'Payment by Results Guidance 2008/09', http://www.dh. gov.uk/prod_consum_dh/groups/dh_digitalassets/@dh/@en/documents/digitalasset/dh_ 081334.pdf [4 March 2011].

Department of Health (2009), 'Patient-Level Information and Costing Systems (PLICS)', http:// www.dh.gov.uk/en/Managingyourorganisation/Financeandplanning/NHScostingmanual/ DH_080056 [24 August 2010].

Department of Health (2010), 'Payment by Results Guidance for 2010-11', http:// www.dh.gov.uk/prod_consum_dh/groups/dh_digitalassets/@dh/@en/@ps/documents/ digitalasset/dh_112970.pdf [17 February 2011].

Department of Health (2011), 'Payment by Results Guidance for 2011-12', http:// www.dh.gov.uk/prod_consum_dh/groups/dh_digitalassets/documents/digitalasset/dh_ 124522.pdf [28 February 2011].

Ellis, R. P. (1998), 'Creaming, skimping and dumping: provider competition on the intensive and extensive margins', Journal of Health Economics, 17(5): 537-555.

Ellis, R. P. and M. Vidal-Fernández (2007), 'Activity-based payments and reforms of the English hospital payment system', Health Economics, Policy and Law, 2(4): 435-444.

Epstein, D. and A. Mason (2006), 'Costs and prices for inpatient care in England: mirror twins or distant cousins'?, Health Care Management Science, 9(3): 233-242.

Ettelt, S. and E. Nolte (2010), 'Funding intensive care - approaches in systems using diagnosisrelated groups', http://www.rand.org/pubs/technical_reports/2010/RAND_TR792.pdf [17 June 2010].

Ettelt, S., S. Thomson, E. Nolte and N. Mays (2006), Reimbursing Highly Specialised Hospital Services: The Experience of Activity-Based Funding in Eight Countries, London: London School of Hygiene and Tropical Medicine.

Farrar, S., J. Sussex, D. Yi, M. Sutton, M. Chalkley, T. Scott and A. Ma (2007), National Evaluation of Payment by Results, Aberdeen: Health Economics Research Unit, University of Aberdeen. 
Farrar, S., D. Yi, M. Sutton, M. Chalkley, J. Sussex and A. Scott (2009), 'Has payment by results affected the way that English hospitals provide care? Difference-in-differences analysis', British Medical Journal, 339: b3047doi:10.1136/bmj.b3047.

Friesner, D. L. and R. Rosenman (2004), 'Inpatient-outpatient cost shifting in Washington hospitals', Health Care Management Science, 7(1): 17-26.

Geissler, A., D. Scheller-Kreinsen and R. Busse (2011), 'Germany: Understanding G-DRGs', in R. Busse, A. Geissler, W. Quentin and M. Wiley (eds), Diagnosis Related Groups in Europe. Moving Towards Transparency, Efficiency and Quality in Hospitals, Maidenhead: Open University Press.

Goldfield, N. (2010), 'The evolution of diagnosis-related groups (DRGs): from its beginnings in case-mix and resource use theory, to its implementation for payment and now for its current utilization for quality within and outside the hospital', Quality Management in Health Care, 19(1): 3-16.

Greß, S., A. Focke, F. Hessel and J. Wasem (2006), 'Financial incentives for disease management programmes and integrated care in German social health insurance', Health Policy, 78(2-3): 295-305.

Häkkinen, U. (2005), 'The impact of changes in Finland's health care system', Health Economics, 14(Supplement 1): S101-S118.

Häkkinen, U. (2010), 'Financing of hospital care in Finland', Euro Observer, 12(3): 10-12. Häkkinen, U. and M. Linna (2005), 'DRGs in Finnish health care', Euro Observer, 7(4): 7-8. Health Service Executive (2008), 'Consultant Contract 2008 - measurement of public:private mix’, http://www.hse.ie/eng/staff/HR/tandc/Consultant_Contract_2008_-_Measurement_ of_Public_Private_Mix.pdf [4 August 2010].

Health Service Executive (2010a), 'Casemix Budget Outturns for 2009', http://www.hse.ie/ eng/services/Publications/corporate/2009casemix.html [12 May 2010].

Health Service Executive (2010b), 'HealthStat - Supporting High Performance', http:// www.hse.ie/eng/staff/Healthstat/about/ [4 August 2010].

Health Service Executive (2010c), HSE National Service Plan 2010, Dublin: Health Service Executive.

Health Service Executive (2010d), National Service Plan 2011, Dublin: Health Service Executive. Henschke, C., M. Bäumler, S. Weid, M. Gaskins and R. Busse (2010), 'Extrabudgetary ("NUB") payments: a gateway for introducing new medical devices into the German inpatient reimbursement system'? Journal of Management \& Marketing in Healthcare, 3(2): 119-133.

Hensen, P., S. Beissert, L. Bruckner-Tuderman, T. A. Luger, N. Roeder and M. L. Muller (2008), 'Introduction of diagnosis-related groups in Germany: evaluation of impact on in-patient care in a dermatological setting', European Journal of Public Health, 18(1): $85-91$.

Jegers, M., K. Kesteloot, D. De Graeve and W. Gilles (2002), 'A typology for provider payment systems in health care', Health Policy, 60(3): 255-273.

Kahn, K. L., L. V. Rubenstein, D. Draper, J. Kosecoff, W. H. Rogers, E. B. Keeler and R. H. Brook (1990), 'The effects of the DRG-based prospective payment system on quality of care for hospitalized Medicare patients: an introduction to the series', Journal of the American Medical Association, 264(15): 1953-1955.

Kautianen, K., U. Häkkinen and J. Lauharanta (2011), 'Finland: DRGs in a Decentralized Health Care System', in R. Busse, A. Geissler, W. Quentin and M. Wiley (eds), Diagnosis Related Groups in Europe. Moving Towards Transparency, Efficiency and Quality in Hospitals, Maidenhead: Open University Press. 
Kimberly, J. R. and G. de Pouvourville and Associates (1993), The Migration of Managerial Innovation: Diagnosis-Related Groups and Health Care Administration in Western Europe, San Francisco: Jossey-Bass Inc.

Kimberly, J. R., G. de Pouvourville and T. D’Aunno (2008), The Globalization of Managerial Innovation in Health Care, Cambridge: Cambridge University Press.

Kittelsen, S. A. C., K. S. Anthun, B. Kalseth, J. Kalseth, V. Halsteinli and J. Magnussen (2009), 'En komparativ analyse av spesialisthelsetjenesten i Finland, Sverige, Danmark og Norge: Aktivitet, ressursbruk og produktivitet 2005-2007', http:// www.sintef.no/upload/Helse/\%C3\%98KT/Pdf-filer/SINTEF_Rapport_A12200-Analyse_ speshelsetjenesten_Finland-Sverige-Danmark-Norge.pdf [2 March 2011].

Kobel, C., J. Thuilliez, M. Bellanger and K.-P. Pfeiffer (2011), 'DRG Systems and Similar Patient Classification Systems in Europe', in R. Busse, A. Geissler, W. Quentin and M. Wiley (eds), Diagnosis Related Groups in Europe. Moving Towards Transparency, Efficiency and Quality in Hospitals, Maidenhead: Open University Press.

Kosecoff, J., K. L. Kahn, W. H. Rogers, E. J. Reinisch, M. J. Sherwood, L. V. Rubenstein, D. Draper, C. P. Roth, C. Chew and R. H. Brook (1990), 'Prospective payment system and impairment at discharge: the "quicker-and-sicker" story revisited', Journal of the American Medical Association, 264(15): 1980-1983.

Kutzin, J. (2001), 'A descriptive framework for country-level analysis of health care financing arrangements', Health Policy, 56(3): 171-204.

Langenbrunner, J., E. Orosz, J. Kutzin and M. M. Wiley (2005), 'Purchasing and Paying Providers', in J. Figueras, R. Robinson and E. Jakubowski (eds), Purchasing to Improve Health Systems Performance, Maidenhead: Open University Press.

Langenbrunner, J. C. and M. M. Wiley (2002), 'Hospital Payment Mechanisms: Theory and Practice in Transition Countries', in M. McKee and J. Healy (eds), Hospitals in a Changing Europe, Buckingham: Open University Press.

Leister, J. E. and J. Stausberg (2005), 'Comparison of cost accounting methods from different DRG systems and their effect on health care quality', Health Policy, 74(1): 46-55.

Linna, M. and U. Häkkinen (2008), 'Benchmarking Finnish Hospitals', in J. Blank and V. Valdmanis (eds), Evaluating Hospital Policy and Performance: Contributions from Hospital Policy and Productivity Research, Oxford: JAI Press.

Linna, M., U. Häkkinen and J. Magnussen (2006), 'Comparing hospital cost efficiency between Norway and Finland', Health Policy, 77(3): 268-278.

Linna, M., U. Häkkinen, M. Peltola, J. Magnussen, K. Anthun, S. Kittelsen, A. Roed, K. Olsen, E. Medin and C. Rehnberg (2010), 'Measuring cost efficiency in the Nordic Hospitals - a cross-sectional comparison of public hospitals in 2002', Health Care Management Science, 13(4): 346-357.

Lungen, M., B. Dredge, A. Rose, C. Roebuck, E. Plamper, K. Lauterbach and The Working Group (2004) 'Using diagnosis-related groups: the situation in the United Kingdom National Health Service and in Germany', European Journal of Health Economics, 5(4): 287-289.

Lungen, M. and I. Lapsley (2003), 'The reform of hospital financing in Germany: an international solution'?, Journal of Health Organization and Management, 17(5): 360-372.

Mannion, R., G. Marini and A. Street (2008), 'Implementing payment by results in the English NHS: changing incentives and the role of information', Journal of Health Organization and Management, 22(1): 79-88.

Mannion, R. and A. Street (2005), Payment by Results and Demand Management: Learning from the South Yorkshire laboratory. CHE Research Paper 14, York: University of York. 
Mason, A. and M. Goddard (2009), Payment by Results in Mental Health: A Review of the International Literature and an Economic Assessment of the Approach in the English NHS. CHE Research Paper 50, York: University of York.

Mason, A., A. Street, M. Miraldo and L. Siciliani (2009), 'Should prospective payments be differentiated for public and private healthcare providers'?, Health Economics, Policy and Law, 4(Pt 4): 383-403.

Mason, A., P. Ward and A. Street (2011), 'England: The Healthcare Resource Group System', in R. Busse, A. Geissler, W. Quentin and M. Wiley (eds), Diagnosis Related Groups in Europe. Moving Towards Transparency, Efficiency and Quality in Hospitals, Maidenhead: Open University Press.

McDaid, D., M. Wiley, A. Maresso and E. Mossialos (2009), 'Ireland: health system review', Health Systems in Transition, 11(4): 1-268.

McNair, P., H. Luft and A. Bindman (2009), 'Medicare's policy not to pay for treating hospital-acquired conditions: the impact', Health Affairs, 28(5): 1485-1493.

Michelot, X. and J.-M. Rodrigues (2008), 'DRGs in France', in J. Kimberly, G. de Pouvourville and T. D'Aunno (eds), The Globalization of Managerial Innovation in Health Care, Cambridge: Cambridge University Press.

Mikkola, H. (2003), 'Hospital pricing reform in the public health care system-an empirical case study from Finland', International Journal of Health Care Finance and Economics, 3(4): 267-286.

Mikkola, H. and U. Häkkinen (2002), 'The effects of case-based pricing on length of stay for common surgical procedures', Journal of Health Services Research and Policy, 7(2): 90-97.

Ministry of Health (2009), 'Rapport 2009 au Parlement sur la tarification à l'activité (T2A)', http://www.sante.gouv.fr/IMG/pdf/Rapport_T2A_2009.pdf [1 March 2011].

Ministry of Health (2010), 'Rapport 2010 au Parlement sur la tarification à l'activité (T2A)', http://www.sante.gouv.fr/IMG/pdf/Rapport_T2A_2010.pdf [1 March 2011].

Miraldo, M., M. Goddard and P. C. Smith (2006), The Incentive Effects of Payment by Results. CHE Research Paper 19, London: Dr Foster Intelligence.

Moreno-Serra, R. and A. Wagstaff (2010), 'System-wide impacts of hospital payment reforms: evidence from Central and Eastern Europe and Central Asia', Journal of Health Economics, 29(4): 585-602.

Newhouse, J. P. (1996), 'Reimbursing health plans and health providers: efficiency in production versus selection', Journal of Economic Literature, 34(3): 1236-1263.

NHS Information Centre (2010), 'Healthcare Resource Groups 4 (HRG4)', www.ic.nhs.uk/ services/the-casemix-service/new-to-this-service/healthcare-resource-groups-4-hrg4 [17 June 2010].

O’Reilly, J., B. McCarthy and M. Wiley (2011), 'Ireland: A Review of Casemix Applications Within the Acute Public Hospital System', in R. Busse, A. Geissler, W. Quentin and M. Wiley (eds), Diagnosis Related Groups in Europe. Moving Towards Transparency, Efficiency and Quality in Hospitals, Maidenhead: Open University Press.

Oliver, A. (2005), 'The English National Health Service: 1979-2005', Health Economics, 14(Supplement 1): S75-S99.

Or, Z. (2009), 'Activity based payment in France', Euro Observer, 11(4): 5-6.

Or, Z. and M. Bellanger (2011), 'France: Implementing Homogeneous Patient Groups in a Mixed Market', in R. Busse, A. Geissler, W. Quentin and M. Wiley (eds), Diagnosis Related Groups in Europe. Moving Towards Transparency, Efficiency and Quality in Hospitals, Maidenhead: Open University Press. 
Or, Z. and U. Häkkinen (2011), 'DRGs and Quality: For Better or Worse'?, in R. Busse, A. Geissler, W. Quentin and M. Wiley (eds), Diagnosis Related Groups in Europe. Moving Towards Transparency, Efficiency and Quality in Hospitals, Maidenhead: Open University Press.

Pronovost, P. J., C. A. Goeschel and R. M. Wachter (2008), 'The wisdom and justice of not paying for "preventable complications", Journal of the American Medical Association, 299(18): 2197-2199.

Propper, C., M. Sutton, C. Whitnall and F. Windmeijer (2007), Did 'targets and terror' reduce English waiting times for elective hospital care?, CMPO Working Paper no. 07/179, Bristol: Centre for Market and Public Organisation.

Rosenberg, M. A. and M. J. Browne (2001), 'The impact of the inpatient prospective payment system and diagnosis-related groups: a survey of the literature', North American Actuarial Journal, 5(4): 84-94.

Scheller-Kreinsen, D., A. Geissler and R. Busse (2009), 'The ABC of DRGs', Euro Observer, 11(4): $1-5$.

Schreyögg, J., T. Stargardt, O. Tiemann and R. Busse (2006a), 'Methods to determine reimbursement rates for diagnosis related groups (DRG): a comparison of nine European countries', Health Care Management Science, 9(3): 215-223.

Schreyögg, J., O. Tiemann and R. Busse (2005), 'The DRG reimbursement system in Germany', Euro Observer, 7(4): 4-6.

Schreyögg, J., O. Tiemann and R. Busse (2006b), 'Cost accounting to determine prices: how well do prices reflect costs in the German DRG-system'?, Health Care Management Science, 9(3): 269-279.

Shleifer, A. (1985), 'A theory of yardstick competition', RAND Journal of Economics, 16(3): 319-327.

Smith, P. C. and A. Street (2005), 'Measuring the efficiency of public services: the limits of analysis', Journal of the Royal Statistical Society. Series A (Statistics in Society), 168(2): 401-417.

Steinbusch, P. J., J. B. Oostenbrink, J. J. Zuurbier and F. J. Schaepkens (2007), 'The risk of upcoding in casemix systems: a comparative study', Health Policy, 81(2-3): 289-299.

Street, A. (2006), 'Reform of Hospital Funding and the Introduction of Patient Choice in England', http://www.york.ac.uk/inst/che/pdf/REES\%205-2\%20English.pdf [24 August 2010].

Street, A. and A. Maynard (2007), 'Activity based financing in England: the need for continual refinement of payment by results', Health Economics, Policy and Law, 2(4): 419-427.

Street, A. and M. Miraldo (2007), 'The impact of the reform of hospital funding in England', Paper presented at Evaluating Health Policy: New Evidence from Administrative Data, University of York, http://www.york.ac.uk/media/che/documents/papers/che-2007impactreform.pdf [15 August 2011].

Street, A., J. O'Reilly, P. Ward and A. Mason (2011), 'DRG-Based Hospital Payment and Efficiency: Theory, Evidence, and Challenges', in R. Busse, A. Geissler, W. Quentin and M. Wiley (eds), Diagnosis Related Groups in Europe. Moving Towards Transparency, Efficiency and Quality in Hospitals, Maidenhead: Open University Press.

Street, A., D. Scheller-Kreinsen, A. Geissler and R. Busse (2010), Determinants of hospital costs and performance variation: methods, models and variables for the EuroDRG Project, Working Papers in Health Policy and Management Volume 3, Berlin: Berlin University of Technology. 
Street, A., K. Vitikainen, A. Bjorvatn and A. Hvenegaard (2007), Introducing activity-based financing: a review of experience in Australia, Denmark, Norway and Sweden, CHE Research Paper 30, York: University of York.

Sussex, J. and S. Farrar (2009), 'Activity-based funding for National Health Service hospitals in England: managers' experience and expectations', European Journal of Health Economics, 10(2): 197-206.

Tan, S. S., L. Serdén, A. Geissler, M. van Ineveld, K. Redekop, M. Heurgren and L. Hakkaart-van Roijen (2011), 'DRGs and Cost Accounting: Which is Driving Which'?, in R. Busse, A. Geissler, W. Quentin and M. Wiley (eds), Diagnosis Related Groups in Europe. Moving Towards Transparency, Efficiency and Quality in Hospitals, Maidenhead: Open University Press.

US Congress Office of Technology Assessment (1985), Medicare's Prospective Payment System: Strategies for Evaluating Cost, Quality, and Medical Technology, Washington, DC: US Government Printing Office.

Vuorenkoski, L., P. Mladovsky and E. Mossialos (2008), 'Finland: health system review', Health Systems in Transition, 10(4): 1-168.

Wiley, M. (2005a), 'Diagnosis Related Groups (DRGs): Measuring Hospital Case Mix', in P. Armitage and T. Colton (eds), Encyclopedia of Biostatistics, Chichester: John Wiley \& Sons, Ltd.

Wiley, M. M. (2005b), 'The Irish health system: developments in strategy, structure, funding and delivery since 1980', Health Economics, 14(Supplement 1): S169-S186. 